\title{
The Contributions of Dr. James Africanus Beale Horton to the Ideals of Pan-Africanism
}

\author{
Dr. John Uzoma Nwachukwu \\ Department of History and International Studies, Ekiti State University, Ado-Ekiti, Nigeria
}

*Corresponding Author: Dr. John Uzoma Nwachukwu, Department of History and International Studies, Ekiti State University, Ado-Ekiti, Nigeria

\begin{abstract}
The paper notes that the fact that Pan-Africanism grew out of the resentment of people of African descent to the degrading attitude of the Whites towards them has given the impression that the protagonists would be those who hated everything about the Whiteman. The paper also notes that the bulk of the protagonists of Pan-Africanism before the twentieth century were New World Africans and that that gave the impression that until the twentieth century nobody born and bred in Africa made any contribution to the ideals of Pan-Africanism. Findings show that somebody born and bred in Africa made a significant contribution to the ideals of Pan-Africanism before the twentieth century. They also show that among the protagonists was a man who eulogized Western civilization and culture. The work made use of secondary data.
\end{abstract}

\section{INTRODUCTION}

Pan-Africanism is a fall out of the trans Atlantic slave trade. It was born and bred in the Americas. This, at any rate, has created the impression that until the twentieth century no African born and bred in the continent had anything to do with the ideals of Pan-Africanism. Again, in view of the fact that Pan-Africanism was a manifestation of the resentment of people of African descent to the dehumanising attitude of the Europeans to them, one would expect that the proponents of the idea would be those who resented Europe and what it stood for. In this paper attempt will be made to show that somebody who was born and bred in Africa contributed to the ideals of Pan-Africanism before the twentieth century. Again, the paper will attempt to show that among those who gave vent to the ideals of Pan-Africanism was a man who revelled in Europe and her civilization.

\section{AN OVERVIEW OF PAN AFricanism}

Pan-Africanism refers to the totality of the efforts made by New World Africans to bring to an end the segregation and other forms of inhuman treatment they received from the Europeans. It aimed at the twin issues of addressing the various issues perceived as being the basis for the ill treatment, and promoting solidarity among people of African descent. That is, Pan-Africanism aimed at arousing in the consciousness of people, especially those connected to Africa, issues like Africa for Africans in ecclesiastical and state matters, rehabilitation of Africa's past, pride in African culture and the hope for a united and glorious future Africa.1 From the foregoing, it can be seen that Pan-Africanism is multidimensional in nature. The multi-pronged nature stems from the fact that in repudiating the below par treatment mentioned above, the blacks tried to justify their positions by correcting the Eurocentric views about them and proferring solutions which they believed would turn things around for the black man.

It is noteworthy that the aforementioned ill treatment of New World Africans by the Whites was a product of the poor perception of the former by the latter. This poor image the Europeans had about the blacks stemmed from how the African Americans got to the Americas. In a nutshell, people of African descent got to the New World as slaves. It may be necessary to point out that slave status, as far as the Europeans were concerned, stripped Africans of any human identity which was why they were treated like cattle. ${ }^{2}$ Put in another, way the Europeans saw the slaves as "property like domestic livestock, to be herded together examined and bartered over". ${ }^{3}$ This position made the Europeans to have no scrupples about the unpalatable treatment they gave the slaves. In the various beats the slaves were engaged in, they had a raw deal. ${ }^{4}$ Things were not better after the abolition of the slave trade as the African Americans were subjected to authorized racial discrimination everywhere in the 
Americas. What happened in the various states attest to this. ${ }^{5}$ Reflecting on the fate of that befell the African Americans, Langley remarked that the emancipation proclaimed for them did not go beyond the paper on which it was written as in the psyche of the Europeans, the Africans were still slaves and, as a result, were treated as such. ${ }^{6}$ On his part, Ofonagoro noted that New World Africans came to realise later that the emancipation supposedly proclaimed for them rather than serve that purpose marked the beginning of a long and difficult fight against authorised racism. ${ }^{7}$

The ills mentioned above were what the African Americans rose up against. The fight back is what has been called Pan-Africanism. It is not as if New World Africans who started it (Pan-Africanism) gave it that name. Rather, it was a label given it in the early years of the twentieth century by people. The name was meant to describe the peculiarity of the phenomenon using its scope. In essence, the name points to the characteristic of the phenomenon, namely, that it is something that pertains to Africa, and cuts across it. The point being made is that for any activity to qualify for the label, PanAfricanism, it must embrace Africa as a whole. In other words, when such an activity is restricted to an individual African, or one or two communities or countries in Africa, it cannot be seen as such. This is because the leaders and/or people involved in them were simply concerned with the narrow interests of their groups. This is why some of the anti colonial activities carried out in different parts of the continent are not seen as expressing Pan Africanist ideals. Examples include the Aba Women's Riot (Nigeria), the Hut Tax War in Sierra Leone and the opposition of King Jaja of Opobo (Nigeria) to British efforts to take his Kingdom. ${ }^{8}$

Another issue worth noting about the phenomenon called Pan-Africanism is that nobody can say with any precision who started it, where it began, (i.e. as regards town or country) and when (i.e. date) it commenced. Nevertheless, It is clear that many black Americans embraced it. The wide acceptance of Pan-Africanism by New World Africans was not a happenstance issue. Rather, it was the product of the sensitisation and/or mobilisation done through the activities of some individuals or groups. Among them were the African Lodge ${ }^{9}$ and a woman called Harriet Tubman. ${ }^{10}$ The activities of this class of African Americans gave New World Africans a psychological upliftment that greatly disposed them to embracing the idea.

\section{CONTRIbUtions OF DR. JAMES HORTON TO THE IdEAls OF PAN-AFRICANISM}

It is in the light of what was said above about the psychological upliftment New World Africans had through the efforts of some individuals and groups that this paper is being written. The focus here is on Dr. James Africanus Beale Horton, an African who was born and bred in the African homeland. However, before going further on this, it is my humble opinion that discussing Dr. Horton's background first is necessary. This is because doing so will go a long way in bringing to light that though Dr. Horton was born and bred in Africa, he was born in an environment where issues were viewed from Europe coloured prism. It will also show that the acculturation programme carried out by the British in Sierra Leone was paternalism at work and it did not really achieve the brainwashing of the Africans as desired by the British.

Dr. Horton was born in Gloucester, Sierra Leone in 1835. Gloucester was one of the settlements where recaptives 11 were resettled. He had his education in both Sierra Leone and Britain. He had a doctorate degree in Surgery and worked in the British Army in West Africa as Staff Surgeon.12 It is necessary to note that the British took full responsibility for the spiritual, intellectual, political and economic rehabilitation of the settlements founded for the recaptives.13 This was why the British Government encouraged Christian missionary groups to establish churches and schools there. Equally encouraged to come were British traders whom they wanted to teach educated Africans modern ways of commerce and how to establish themselves. The British did the above because they wanted to effect a socio-cultural engineering programme among the settlers. The British desired the acculturation because the settlers were meant to be agents for the propagation of European civilization in other parts of West Africa. At any rate, the British succeeded in the acculturation programme because the settlers revelled in Western civilisation and culture so much that they became lodestar to look upto. ${ }^{14}$

That was the environment Dr. Horton grew in and like one who grew up in that environment he was not unaffected by it.15 The above notwithstanding, Dr. Horton did not fail to speak up for Africa when the need arose. What brought this about was the negative comments about the Blacks that was pervasive in Europe in the second half of the nineteenth century. In a nutshell, the Blacks were 
presented as inferior to the Whites. In line with the prevailing view in Europe, the London Anthropological Society sought to provide a basis for their positions. So intense was the propaganda that the conducive environment that gave birth to the Sierra Leone project fizzled out. The educated Blacks who were not spared by the baiting, as a result, lost the courage to challenge it.[16] But not Dr. Horton. Using his knowledge of science, Dr. Horton deflated the position of the racial anthropologists. The significance of Dr. Horton's response lies in the fact that it was a shift from the religion based response people of African descent had been giving. In assessing the impact of what Dr. Horton did on the development and growth of Pan- Africanist ideals, P.O. Esedebe said that it "rendered the highway of Pan Africanism much clearer, firmer and safer" 17

Another of Dr. Horton's contributions is in the issue of glorious past for Africa. To appreciate what Dr. Horton did in this regard, one needs to understand that the racial propagandists claimed that there was no achievement worth mentioning that came from Africa.18 Being one with a voracious appetite for knowledge Dr. Horton ventured into classics, history and anthropology. With the knowledge he got from them, Dr. Horton came up with the story of glorious past of Africa. According to him, Africa was the nursery of science and literature and that so high was the level of Africa's education that renowned names like Pythagoras, Solon and Plato, among others, came to Africa to learn. He further said that the Greeks represented Minerva, goddess of Wisdom, as an African princess in acknowledgement of Africa as the source of knowledge. In addition to the above he deposed that many of the renowned theologians of the early Church were Africans. Among the names he mentioned were Origen, Augustine, Cyril, Tertullian, Clemens and Alexandrinus. ${ }^{19}$

Still using the knowledge he got from those disciplines, Dr. Horton deposed that history has shown that change is an inevitable aspect of human society. This, he claimed was why the torch of world civilisational progress has always moved from one point to the other. According to him a flourishing and civilised state would later degenerate into a semi-barbarous state and vice versa. He buttressed his point by citing the example of Britain which he said was barbarous at the peak of the Roman power. With this at the back of his mind, he posited that Africa which had been at the top before would go back there again. Horton's optimism, it may be necessary to state, was not based on mere sentiments, but on the degree of improvement exhibited by the recaptives under missionary influence which he said far exceeded that made by Britain under Roman influence during a similar period of time. ${ }^{20}$

Dr Horton equally used the achievements of his fellow Blacks to show the hollowness of the propaganda about negro inferiority. According to him, what he and other blacks were able to achieve showed that if the Blacks were not fettered there was no limit to what they could achieve. Dr Horton needed to say this because part of the propaganda against the Blacks was that the backwardness of Africa and her people was an innate thing rather that their being fettered.21 Some of the Africans Dr Horton had in mind were G.G Nicol, James Quaker, Christian Cole, William Grant, J.C Taylor and Williams Davies. These were all people of humble background who, by dint of hard work, achieved much educationally and, as a result, went far on the socio economic ladder.22 Hensbroek corroborated Dr Horton's position when the deposed that the careers of Dr Horton and the other Blacks " refuted in most concrete form contemporary racial prejudice".23 Added to this, Dr Horton pointed to the resilience of Africans as evidence that they were not in any way inferior to the Whites. This resilience could be seen in what the Blacks endured in the course of the slave trade 24 and the way they mastered the language and skills of Europe within so short a time that they became successful in various fields.25 Put in another way, Dr Horton was saying that Africans should be seen as "a permanent and enduring people" 26 since they could thrive in any environment.

There are still other issues that show the Pan-Africanist inclinations of Dr. James Horton. This could be seen in his refusal to restrict himself to Creole or Sierra Leone issues alone. Rather he pursued things that advanced the cause of Africa and her peoples. An example could be seen in what he did when the British and the Dutch exchanged forts in what is today Ghana. In a nutshell, he pitched his tent with the Africans. He did a similar thing when the local British administration strongly opposed the formation of Fante Confederation. The support he gave the Confederation nearly cost him his job, but he was not deterred.27 He was really passionate about Africa and desired that the continent be at the top. According to Nwachukwu and Adu, Horton's "vision for West Africa and by extension Africa was that of an entity that would be viable economically, technically and other fronts." 28 To achieve this, he argued against the exclusion of foreign agencies in the development drive in Africa. According to him, this would not diminish the stature of Africa as something similar happened to 
Europe and America before they got to their levels.29 Another way Dr Horton believed his vision could be achieved was through having a functional education. Thus, he advocated education that had adequate technical and vocational contents. In addition, he advocated active government participation in education and that it be free and compulsory. This position of his was informed by the tight economic situation of Africans which made it very difficult for many to be educated up to post primary school level. To appreciate his position, one needs to know that for him, education was the assured instrument for bringing about a glorious future for Africa. This explains why he made a case for a university in West Africa.

From the foregoing it can be seen that the efforts of an African from the African homeland contributed to strengthening the concept of Pan-Africanism. It can also be seen that Pan-Africanism was a revolt against injustice to the Black race and that it was an irresistible option for people of African descent notwithstanding the level of paternalism adopted by the Europeans in their dealings with the Blacks. This was why Dr. Horton could speak up for Africa and her peoples despite his Anglophile nature. That is, so long as Africans were not subjected to any form of dehumanization by the Whites or if they remained unaware of such, there was usually no assertion of the African identity.

\section{REFERENCES}

[1] P.O. Esedebe; “"Pan-Africanism' Origins and Meaning”, Tarikh Vo1.6 No. 3, p.14

[2] M.L Conniff and T.J. Davis; Africans in the Americas: A History of the Black Diaspora (New Jersey: the Blackburn Press, 2002) p.46

[3] K. Shillington; History of Africa (London; Macmillan, 1989) p. 176

[4] M.L Conniff and T.J Davis; Africans in the Americas... pp 48-51

[5] See W.I. Ofonagoro; "The African Presence in North America", Tarikh 20, Vol 5, No 4 pp 64-67, P.O. Esedebe; Pa- Africanism: The Idea and Movement, 1776-1991 (Washington D.C. Howard University Press, 1994) pp 9-13, M.L Conniff and T.J. Davis; Africans in the Americas. Pp. 145-149, J.A. Langley; Pan-Africanism and Nationalism in West Africa, 1990-1945: A Study in Ideology and Social Classes (Oxford, Clarendon Press, 1978) pp 17-24.

[6] J.A. Langley; Pan-Africanism and Nationalism... p. 17

[7] W.I. Ofonagoro; " The Africanism Presence in North America"... p. 66

[8] P.O. Esedebe; Pan-Africanism: The Idea and Movement, 1776-1991 ... p.6

[9] Ibid pp. 8-9

[10] M. L. Conniff and T.J. Davis. Africans in the Americas... p.193 see also w.I. Ofonagoro; "The African Presence in North America"....p. 64

[11] Recaptives refer to the Africans who were sold as slaves but did not get to the New World because the British Naval Squadron intercepted them on the high seas and resettled them in Sierra Leone. The term also applied to their descendants. They are also called Krio, Creole or Aku.

[12] J. U. Nwachukwu and F. M. Adu; "James Africaus Beale Horton and His Theory of External Stimulus and African Development" in A. A. Agagu and F.Omotoso (eds); Selected Issues in African Political Thought (Porto Novo: L'Institute Universitaire Sonou D' Afrique, 2007) p. 75

[13] E.A. Ayandele; African Historical Studies (London. Frank Cass, 1979) pp 165-6

[14] J.U. Nwachukwu and F.M Adu; " James Africanus Beale Horton and His Theory... P. 76.

[15] R. W. July; The Origins of Modern African Thought: Its Development in West Africa in the Nineteenth and Twentieth Centuries (London: Faber and Faber, 1968) pp. 112-113.

[16] J. U. Nwachukwu and F. M. Adu; "James Africanus Beale Horton and His Theory... p. 77.

[17] P. O. Esedebe; Pan-Africanism: The Idea and Movement, 1776-1991 ... p. 21

[18] Ibid p. 16

[19] Ibid p. 21

[20] P. B. Van Hensbroek;' African Political Philosophy, 1860-1995: An Inquiry into Families of Discourse (Groningen: Centre for Development Studies, university of Groningen, 1998) pp. 37-38

[21] P. O. Esedebe; Pan-Africanism: The Idea ... p. 16.

[22] J. U. Nwachukwu and F.M. Adu; “James Africanus Beale Horton ...” p. 77

[23] P. B. Van Hensbroek; African Political Philosophy... p.37

[24] E. A. Ayandele; African Historical Studies.... P. 18

[25] A. Wyse; The Krio of Sierra Leone: An Interpretative History (London: C. Hurst and Co., 1989) p. 5.

International Journal of History and Cultural Studies (IJHCS)

Page $\mid 68$ 
[26] Quoted in p. O. Esedebe; Pan-Africanism: The Idea.... P. 21

[27] J. U. Nwachukwu and F.M. Adu; “ James Africanus Beale Horton .....” p. 79

[28] Ibid p. 80

[29] P. O. Esedebe; Pan-Africanism: The Idea... p. 20.

[30] J. U. Nwachukwu and F.M. Adu; “ James Africanus Beale Horton .....” p. 80

\section{AUTHORS' BIOGRAPHY}

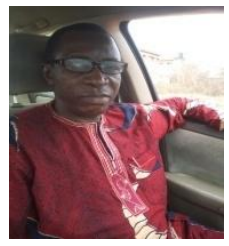

Dr. John Nwachukwu is a lecturer in the department of History and International Studies, Ekiti State University, Ado Ekiti, Nigeria. His areas of interest are: Economic History and Intellectual History. He has published in numerous reputable journals both locally and international.

Citation: Dr. John Uzoma Nwachukwu. "The Contributions of Dr. James Africans Beale Horton to the Ideals of Pan-Africanism". International Journal of History and Cultural Studies (IJHCS). vol 5, no. 1, 2019, pp. 69-69. doi: DOI: http://dx.doi.org/ 10.20431/2454-7654.0501007.

Copyright: (C) 2019 Authors. This is an open-access article distributed under the terms of the Creative Commons Attribution License, which permits unrestricted use, distribution, and reproduction in any medium, provided the original author and source are credited. 